\title{
INTERCULTURAL COMMUNICATION KELOMPOK SAMIN DAN MASYARAKAT SEKITAR(OUTGROUP): KAJIAN ANXIETY/UNCERTAINT MANAGEMENT THEORY
}

\author{
Intan Kurnia Syaputri*
}

\begin{abstract}
Abstrack
This paper wants to tell about how intercultural communication is intertwined in the community of Samin community and the outside community around the Samin area. The author uses the position of emic approach that sees from the perspective of the Samin group. The author focuses only on the anxiety and uncertainty that occurs. This difference in cultural background certainly affects communication between them. Different cultures and ways of communicating with Samin groups and communities around this Samin may cause various obstacles. Some of the obstacles in question are anxiety and uncertainty between the two parties. Samin groups can be called mindless groups in communicating because Samin groups do not fully pay attention to what they say and do and can not categorize their interlocutors. Samin groups will become mindful when they can be slightly open to information coming from outside the group and acknowledge that there are multiple perspectives for interpreting messages in intercultural communication situations so that communication with outgroups is more effective.
\end{abstract}

Kata Kunci: Komunikasi Antarbudaya, Anxiety, Uncertainty, Kelompok Samin

\section{Pendahuluan}

Paper ini ingin bercerita tentang bagaimana komunikasi antarbudaya yang terjalin pada komunitas Samin dan masyarakat luar (outgroup) disekitar wilayah Samin.Perbedaan latar belakang budaya ini tentunya mempengaruhi komunikasi diantara mereka. Dalam kebudayaan ada sistem dan dinamika yang mengatur cara pertukan simbol dan hanya dengan komunikasilah pertukaran simbol-simbol dapat dilakukan. ${ }^{2}$

Kebudayaan yang berbeda memiliki sistem yang berbeda pula dalam mengatur simbol-simbol dalam komunikasi. "It (culture) is thefoundation of communication; and when cultures vary, communication practices may also vary" (budaya adalah dasar dari komunikasi; jika budaya berbeda, maka praktik komunikasi juga berbeda). ${ }^{3}$

Dikarenakan perbedaan tersebut komunikasi yang terjadi diantara mereka termasuk dalam komunikasi antarbudaya. Komunikasi antarbudaya adalah "communication between people whose cultural perceptions and symbol system are distinct enough to alter the communication event" (komunikasi diantara orang-orang yang persepsi budaya dan sistem simbolnya cukup berbeda untuk mengubah peristiwa komunikasi) ${ }^{4}$.

Berbedaan budaya dan cara berkomunikasi pada kelompok Samin dan masyarakat di sekitar Samin ini mungkin menimbulkan berbagai hambatan. Beberapa

* Penulis adalah Dosen Jurusan Dakwah IAIN Bengkulu 
dari hambatan yang dimaksud adalah anxiety (kecemasan) dan uncertainty (ketidakpastian) diantara kedua belah pihak. Gudykunst ${ }^{5}$ menyatakan bahwa ketika orangorang dari latar belakang budaya yang berbeda bertemu, mereka mengalami anxiety dan uncertainty terhadap satu sama lain. Hal tersebut dapat dikelola untuk tetap mencapai komunikasi antarbudaya yang efektif. Gudykunst ${ }^{6}$ menyatakan, "when we interact with strangers, our ability to communication effectively is based,... on our ability to manage our anxiety and uncertainty" (ketika kita berinteraksi dengan orang asing yang berbeda latar belakang budaya-, kemampuan kita untuk berkomunikasi secara efektif didasarkan pada kemampuan untuk mengelola anxiety dan uncertainty kita).

Untuk dapat mengelola anxiety dan uncertainty, seseorang harus mindfull dalam berkomunikasi. Mindfulness adalah proses dimana seseorang secara sadar mengelola anxiety dan uncertainty terhadap orang lain untuk mencapai komunikasi yang efektif.' Dari pemaparan fenomena dan sedikit ulasan teori yg penulis sampaikan pada latarbelakang, paper ini ingin bercerita tentang komunikasi antarbudaya yang terjalin pada masyarakat komunitas Samin dan masyarakat luar disekitar Samin yang mempunyai hambatanhambatan berkomunikasi karena perbedaan latar belakang budaya.Penulis memakai posisi pendekatan emic, penulis menganalisis melihat dari perspektif kelompok Samin. Begitupun pembahasan dalam paper ini, penulis menganalisis berangkat dari adanya fenomena komunikasi antarbudaya antara kelompok Samin dan masyarakat sekitarnya dengan memakai salah satu teori komunikasi antarbudaya sebagai pperspektif yang hanya berfokus pada anxiety dan uncertaintymanagement.

\section{Pembahasan}

\section{Latar Belakang Kemunculan Kelompok Samin}

Pada tahun 1890-an, residen Belanda di Blora dibuat bingung oleh ulah sekelompok warga Bapangan yang menolak untuk membayar pajak pada petugas controleur dengan alasan mereka tidak meminjam tanah kepada siapapun sehingg mereka tidak mempunyai kewajiban untuk membayar. Samin Surosentiko,seorang petani pemilik sawah seluas tiga hektar di desa Randublatung, menjadi pelopor gerakan pembangkangan terhadap petugas pajak pemerintah kolonial Belanda.

Beberapa peneliti di kemudian hari mencoba melacak penyebab utama ide pembangkangan yang dilakukan oleh petani di wilayah Jawa Tengah dan sebagian kecil Jawa Timur ini. Lance Castle dan Harry menyimpulkan bahwa keterpurukan ekonomi lah yang menyebabkan munculnya ide pembangkangan, tetapi pendapat ini kemudian dibantah oleh Victor King yang mengatakan bahwa mendudukan faktor ekonomi sebagai determinan bagi gerakan ini bukanlah sebuah jawaban karena menurutnya ada beberapa kelompok petani miskin yang memilih untuk tidak mengikuti gerakan ini. King mengajukan kesimpulan bahwa gerakan 
ini merupakan aksi petani kelas menengah yang tidak lagi memiliki posisi dalam tatanana sosial ekonomi masyarakat petani di Jawa pasca-ketentuan pemungutan pajak oleh pemerintah kolonial. Kesimpulan yang monokausalitas juga terlihat dalam tulisan Nancy Peluso yang menuliskan bahwa kebijakan kehutanan pemerintah kolonial Belanda yang menjadi latar belakang munculnya gerakan Saminisme9.

Pemaknaan secara politis terhadap gerakan Saminisme juga dilakukan oleh beberapa penulis yang, menurut Amrih Widodo, sangat ditentukan oleh posisi ideologis penulis tersebut. Tjipto Mangunkusumo, seorang anti-kolonialis tulen, mengatakan bahwa Saminisme merupakan embrio gerakan komunisme yang akan melawan kolonialisme di Indonesia. Asumsi yang lekat dalam argumennya adalah Saminisme akan pudar ketika tujuan gerakan ini telah tercapai, yaitu kemerdekaan dari kolonialisme. Asumsi ini yang sering digunakan ketika membaca gerakan milleniarisme.

Penjelasan yang dikatakan Tjipto Mangunkusumo mendudukkan Saminisme dalam term gerakan milleniarisme atau gerakan "Ratu Adil". Ciri gerakan ini adalah memiliki pemimpin, gerakan radikal, sporadis dan berdurasi pendek. Tetapi, menurut Uzair Fauzan, gerakan perlawanan ini tidak hanya menjadi suatu bentuk resistensi tetapi telah melebur menjadi sebuah kepercayaan dan nilai hidup bagi pengikut Saminisme sehingga gerakan ini tetap eksis hingga hari ini ${ }^{10}$.
Pemerintah Indonesia sendiri di setiap zamannya memiliki pemaknaan yang berbeda terhadap Saminisme. Orde Lama menjadikan gerakan Saminisme sebagai ikon perlawanan terhadap kolonialisme tetapi juga menjadi kelompok masyarakat yang harus ikut dicerdaskan sesuai dengan tujuan pendirian Indonesia yang termuat dalam pembukaan UUD 1945. Selanjutnya keinginan untuk menjauhkan diri dari memori masa lalu menjadi satu dasar pemberadaban yang dilakukan oleh Orde Baru. Nasionalisme yang sebelumnya merupakan resentiment terhadap kolonialisme telah menemukan musuh baru yaitu ekspresi lokal yang dianggap menghambat proses pembentukan sebuah nation yang bernama Indonesia ${ }^{11}$. Praktik sterilisasi ideologi yang dilakukan oleh Orde Baru pasca peristiwa berdarah 1965 juga dialami oleh Masyarakat samin. Tindakan koersif menjadi pilihan dari rezim Orde Baru pada permulaan kemunculannya untuk dapat menghilangkan potensi-potensi pembangkangan.

\section{Sekilas Samin}

Masyarakat Samin, seperti telah dijabarkan di atas, sering dilahat sebagai sebuah komunitas berbasis tradisi yang muncul sebagai akibat dari adanya sebuah ketokohan kharismatik. Ialah Kyai Surosentiko (Kyai Samin Anom) yang pada tahun 1900an mulai menyebarkan ajarannya dalam Serat Jamus Kalimasada kepada orang-orang di wilayah Bojonegoro dan Blora. Ajaran ini pada intinya adalah ajakan untuk menjalani hidup dengan sederhana, 
yang sekaligus juga merupakan wujud dari sikap Kyai Samin yang mengajak masyarakat di sekitarnya untuk tidak tunduk terhadap pemerintah kolonial pada masa itu, yang dianggapnya merugikan dan menindas kaum pribumi. Nama Samin itu sendiri berasal dari kata sami-sami amin atau sama senasib.

Masyarakat Samin kemudian menyebut diri sebagai Sedulur Sikep, yang tetap melestarikan ajaran Kesaminan dengan prinsip kesederhanaan dan sikap "pembangkangan" terhadap pemerintah dengan kebiasaan tidak mengikuti sejumlah aturan yang dibuat oleh pemerintah.Hingga saat ini, masyarakat Samin masih berdiam di wilayah Pati dan Blora dengan tradisi yang terus dilestarikannya. Hal ini menyebabkan muncul semacam stereotip dari msyarakat bahwa warga Samin adalah sekumpulan masyarakat yang terbelakang, lugu dan tidak lebih dari sebuah masyarakat tradisional yang bersikap puritan. ${ }^{12}$

\section{Konsep Ajaran Samin}

Pawelinge Ki Surosentiko Samin dhateng para anak putu sedaya Aja ninggalke tata carane madepo kanthi teguh Aja melu kang ngaku suci pilahen kanthi waspada Mlebu nang gegayuhanipun kanggo nggayuh kamerdhikan

Sami netepna rasa kang nyawiji

kanthi adil lan merdhika ${ }^{13}$

Sebuah tembang jawa yang berisi tentang pesan Ki Samin Surosentiko kepada anak cucunya menjadi penutup sebuah film dokumenter berjudul Kula Ndika Sami. Pesan yang berisi peringatan untuk tidak serta merta menjadi pengikut orang-orang yang mengaku sebagai orang yang suci dan selalu menjaga kewaspadaan untuk dapat mewujudkan keadilan dan kemerdekaan dalam kehidupan mereka. Termasuk didalamnya keadilan dan kemerdekaan untuk tidak memilih agama yang "dijajakan" oleh negara. ${ }^{14}$

Sikap dan perilaku yang dijalankan oleh Masyarakat samin tersebut pada akhirnya menimbulkan multi tafsir. Ada yang menganggap bahwa Masyarakat Samin mungkin saja hanya sebuah komunitas yang memiliki tradisi berbeda dengan komunitas lain. Mereka meyakini dan melestarikan pokok-pokok ajaran yang pernah disebarkan oleh leluhur mereka. Namun kemudian para pakar dan masyarakat luas menyebut tradisi komunitas ini sebagai sebuah gerakan membangkang terhadap pemerintah (civil disobedience). Tak hanya melakukan penolakan terhadap agama "negara" mereka juga memiliki lima ajaran utama yang lain:(a) tidak bersekolah, (b) tidak memakai peci, tapi memakai “iket”, yaitu semacam kain yang diikatkan di kepala mirip orang Jawa dahulu, (c) tidak berpoligami, (d) tidak memakai celana panjang, dan hanya pakai celana selutut, (e) tidak berdagang. (penolakan terhadap kapitalisme).

Ajaran Samin pada intinya lebih menjelaskan kerangka cita-cita kemanusiaan. Menurut Kyai Samin Surosentiko adalah membangun kebudayaan yang paling inti dengan melakukan perkawinan dalam ajaran 
kesaminan. Perkawinan adalah wadah prima bagi manusia menekuni kesunyatan. Bukan saja karena nanti perkawinan membuahkan keturunan yang akan meneruskan sejarah hidup manusia, tapi karena sarana ini menegaskan hakekat ketuhanan, berhubungan antara pria dan wanita, rasa sosial dan kekeluargaan, dan tanggung jawab.

Konsep ajaran Masyarakat Samin masuk dalam kategori Budaya Masyarakat Samin: Keseimbangan, harmonisi dan kesetaraan keadilan.Adalah prinsip dan falsafah hidup masyarakat Samin tetap diyakini sampai saat ini. Dengan menjaga budaya dan tradisi lisan kepada generasi dan keturunan tingkat ke 4. Tradisi lisan ini berbentuk puisi, tembang, dan macapat. Ajaranpokok masyarakat Samin tertuang dalam Kitab Serat Jamus Kalimasada, yang sebenarnya hanya sebuah buku yang berisi kumpulan-kumpulan falsafah dan petuah hidup manusia.Kitab Serat Jamus Kalimasada ditulis oleh Kyai Samin Surowijoyo yang terdiri dari Serat Punjer Kawitan, Serat Pikukuh Kasajaten, Serat Uri Uri Pambudi, Serat Jati Sawit, dan Serat Lampahing Urip, yang mana seluruhnya memiliki ide tentang membangun negara batin yang jauh dari sikap tercela. ${ }^{15}$

\section{Anxiety/Uncertainty Management \\ Theory}

Gudykunst ${ }^{16}$ mengasumsikan bahwa minimal satu orang dalam sebuah pertemuan (komunikasi) antarbudaya adalah orang asing (stranger). Penggunaan istilah orang asing mengacu pada orang-orang yang menjalani hubungan yang mana didalamnya terdapat tingkat keasingan yang tinggi dan tingkat familiaritas yang rendah. Keasingan yang tinggi dan familiaritas yang rendah bisa muncul karena tidak adanya pengetahuan yang cukup tentang orang yang baru ditemui untuk pertama kali. ${ }^{17}$ Pengetahuan yang dimaksud bisa tentang budaya, orientasi nilai, sikap dan perilaku.

Dalam komunikasi antarbudaya dimana orang asing terlibat di dalamnya, orang asing tersebut mengalami anxiety dan uncertainty yang dapat menghambat tercapainya komunikasi efektif. Penelitian yang dilakukan Gudykunst menunjukan bahwa anxiety dan uncertainty selalu muncul persamaan, perbedaannya terletak pada anxiety adalah hal efektif atau emosi, sedangkan uncertainty adalah hal kognitif.

\section{Anxiety and Uncertainty}

Gudykunst ${ }^{18}$ mendefinisikan anxiety sebagai perasaan khawatir, tegang, takut atau gelisah atas apa yang mungkin terjadi saat berkomunikasi dengan orang asing. Anxiety yang dialami biasanya disebabkan oleh adanya dugaan-dugaan negatif terhadap orang asing tersebut. Hal tersebut menyebabkan komunikasi yang terjadi penuh dengan dugaan-dugaan atau prasangka.Anxiety selalu muncul dalam setiap peristiwa komunikasi. Anxiety akan lebih meningkat ketika berkomunikasi dengan orang asing dalam konteks antarbudaya.

Berkaitan dengan hal tersebut, setiap orang memiliki tingkat anxiety yang berbedabeda. Jika anxiety sangat tinggi, seseorang 
dapat dipastikan akan kesulitan bahkan tidak mau berkomunikasi dengan orang asing. Seseorang hanya akan menggunakan stereotip dalam memprediksi perilaku orang asing, padahal stereotip tidak selalu tepat pada setiap individu.

Sedangkan uncertainty didefinisikan sebagai keraguan atas kemampuan untuk memprediksi hasil dari interaksi dengan orang asing, termasuk juga keraguan tentang apa yang telah kita lakukan. Berger $\&$ Calabrese ${ }^{19}$ menyimpulkan bahwa ada dua jenis uncertainty yang muncul ketika berkomunikasi dengan orang asing.

Pertama, uncertainty terhadap sikap, perasaan, kepercayaan, nilai dan perilaku orang asing. Ketika berkomunikasi dengan orang asing, seseorang perlu untuk dapat memprediksi perilaku yang akan ditunjukan oleh orang asing yang dihadapi. Prediksi yang dibuat berfungsi untuk mengurangi uncertainty yang dirasakan. Dengan membuat prediksiprediksi tentang perilaku orang asing yang mungkin ditunjukannya, seseorang dapat menentukan perilaku untuk berkomunikasi dengan orang asing yang dihadapi.

Kedua, uncertainty terhadap makna dibalik perilaku yang ditunjukan oleh orang asing ketika berkomunikasi. Dalam hal ini, seseorang berusaha untuk mengurangi uncertainty dengan memprediksi maknamakna yang mungkin sesuai dengan perilaku orang asing tersebut. Hal ini bermanfaat ketika seseorang ingin memahami perilaku orang asing sehingga mampu meningkatkan kemampuan untuk memprediksi perilaku orang asing tersebut pada kesempatan yang akan datang.
Uncertainty selalu muncul dalam setiap peristiwa komunikasi, uncertainty akan lebih meningkat ketika berkomunikasi dengan orang asing dalam konteks antrarbudaya. Sama halnya dengan anxiety, setiap orang juga memiliki tingkat uncertainty yang berbedabeda. Jika uncertainty sangat tinggi, seseorang akan merasa tidak nyaman berkomunikasi dan tidak percaya diri untuk membuat prediksiprediksi dikarenakan kurangnya informasi yang dimiliki tentang orang asing yang dihadapi.

Jika uncertainty sangat rendah, seseorang akan berpikir bahwa prilaku orang asing akan sangat mudah untuk diprediksi. Seseorang menjadi sangat percaya diri untuk memprediksi orang asing karena ia memiliki cukup informasi tentang orang asing tersebut. Akan tetapi, informasi yang dimiliki tersebut tidak selalu menjamin bahwa prediksi yang dibuat sudah tepat. Ketika seseorang terlalu percaya diri, ia akan sangat mungkin melakukan kesalahan interpretasi terhadap prilaku orang asing karena ia tidak memperhitungkan bahwa mungkin saja prediksi yang dibuatnyatidak tepat.

\section{Faktor-faktor yang Mempengaruhi Anxiety/Uncertainty}

Gudykunst ${ }^{20}$ menyatakan bahwa ketika berkomunikasi dengan orang asing, kemampuan seseorang untuk berkomunikasi secara efektif didasarkan pada kemampuan untuk mengelola anxiety dan uncertainty. Ada berbagai macam faktor yang mempengaruhi anxiety dan uncertainty seseorang. Faktorfaktor tersebut berupa pengaruh sosiokultural, psikokultural dan lingkunga. 
Stephen \&Stephen ${ }^{21}$ menyimpulkan tiga kategori yang mempengaruhi anxiety seseorang. Ketiga kategori tersebut adalah hubungan antar kelompok yang telah lebih dulu terbangun, kesadaran dan pengetahuan antarkelompok serta faktor situasional. Hubungan antarkelompok yang telah lebih dulu terbangun berhubungan dengan seberapa jauh hubungan yang telah terbangun dan dalam kondisi seperti apa hubungan tersebut terbangun. Semakinjauh hubungan terbangun dan semakin jelas norma-norma diantara dua kelompok, maka semakin berkuranglah anxiety yangakan dialami.Akan tetapi apabila pernah terjadi konflik diantara kedua kelompok, maka anxiety justru dapat meningkat.

Gudykunst ${ }^{22}$ menyimpulakn beberapa faktor yang mempegaruhi uncertainty. Faktor-faktor tersebut adalah: expectation (dugaan), social identity (identitas sosial), persepsi atas kesamaan diantara kelompok sendiri dengan kelompok orang asing dan halhal interpersonal yang menonjol dalam komunikasi dengan orang asing.

Gudykunst \& Hammer ${ }^{23}$ menyatakan bahwa identitas sosial yang kuat dapat mengurangi uncertainty. Seseorang dapat menerima bahwa orang asing berasal dari kelompok yang berbeda, dan juga bahwa orang asing yang dihadapi memiliki karakter yang khas yang mungkin berbeda dengan anggota kelompoknya yang lain.

Banyak sedikitnya kesamaan antara kelompok sendiri dengan kelompok orang asing juga mempengaruhi kemampuan seseorang dalam mengurangi uncertainty. ${ }^{24}$
Jika seseorang merasakan kelompoknya memiliki kesamaan dengan kelompok lain yang dihadapi, kepercayaan dirinya dalam memprediksi perilaku orang lain akan meningkat. Akan tetapi kesamaan yang dirasakan tidak selalu dapat meningkatkan kemampuan seseorang dalam memprediksi perilaku orang asing. Hal ini terjadi apabila seseorang merasakan ada persamaan, tetapi sebetulnya berbeda atau merasakan perbedaan tetapi sebetulnya sama. Pengetahuan akan persamaan dan perbedaan diantara dua kelompok sangat dibutuhkan untuk mengurangi uncertainty.

Jaringan komunikasi antara seseorang dengan orang asing juga mempengaruhi uncertainty. Jaringan yang dimaksud adalah ada tidaknya mereka dari dua kelompok itu saling mengenal. Selain itu keinginan untuk membangun hubungan lebih jauh dengan orang asing juga dapat mengurangkan uncertainty. Ketika seseorang tertarik dengan orang asing baik secara individual maupun secara sosial, kepercayaan dirinya untuk memprediksi prilaku orang asing tersebut akan meningkat. Dalam hal ini, pengetahuan tentang budaya dan bahasa akan sangat membantu.

\section{Analisis Fenomena \\ 1. Komunikasi Budaya Kelompok Samin dan Masyarakat Sekitar di Tinjau dari Teori Anxiety/ Uncertainty}

Berpijak pada teori AUM yang bertujuan untuk menghasilkan komunikasi antarbudaya yang efektif, paper ini akan 
menganalisis anxiety dan uncertainty yang terjadi pada kelompok Samin dan masyarakat sekitar.Komunitas Samin hidup berke-lompok, masyarakat sekitar menganggap bahwa kelompok ini merupakan kelompok yang asing bagi mereka karena komunitas Samin memiliki aktivitas sendiri dalam pemukiman, sehingga mereka jarang keluar dari pemukiman.

Gudykunst $^{26}$ menjelaskan bahwa unxiety dan uncertainty muncul selalu bersamaan, yang membedakannya adalah unxiety cenderung mempengaruhi ketidakefektifan komunikasi yang terjalin dan sikap emosional seseorang saat berkomunikasi dengan orang asing dan uncertainty ini lebih kepada kognitif seseorang saat menangkap pembicaraan dengan lawan bicara. Hal seperti ini juga sering terjadi diantara kelompok Samin dan masyarakat sekitar. Seperti hasil penelitian yang dilakukan Rini Damayanti ${ }^{27}$ tentang interaktifitas antara komunitas Samin dan Masyarakat sekitar mengungkapkan kelompok Samin dan outgroup nya jika berpapasan dijalan juga bertegur sapa (senyum dan menganggukan kepala) tetapi antara mereka juga sering terjadi kesalahpahaman karena perbedaan budaya. Misalnya dalam segi bahasa, kelompok Samin mempunyai bahasa sendiri yaitu bahasa Jawa Ngoko,akibatnya sering terjadi ketidakpastian komunikasi antara keduanya. Apa yang dimaksudkan oleh masyarakat sekitar kadang berbeda pemaknaannya bagi kelompok Samin, sehingga me-nimbulkan percekcokanpercekcokan kecil.
Pada kelompok Samin dan masyarakat sekitar juga mengalamianxiety, dimana Gudykunst ${ }^{28}$ mendefinisikan anxiety sebagai perasaan khawatir, tegang, takut atau gelisah atas apa yang mungkin terjadi saat berkomunikasi dengan orang asing. Kelompok samin yang mempunyai bahasa sendiri dengan masyarakat lain membuat mereka merasa takut untuk berkomunikasi dengan orang lain, ini ditunjukan dengan kelompok Smin jarang keluar dari pemukiman tempat tinggalnya, mereka lebih nyaman berkomunikasi dengan sesama kelompoknya. Kecuali ada hal-hal atau undungan dari masyarakat sekitar atau aparat pemerintah desa (undangan yang bersifat formal).

Adanya dugaan-dugaan negatif terhadap masyarakat luar juga di alami oleh kelompok Samin. Masyarakat beranggapan bahwa kelompok Samin itu "aneh" mempunyai sikap yang "nyeleneh" semua ini tidak terlepas dari historis kemunculan komunitas Samin dahulu. Sehingga komunikasi yang terjadi antara kelompok Samin dan masyarakat sekitar penuh dengan dugaan-dugaan atau prasangka.Selain ketakutan dalam berkomunikasi karena perbedaan bahasa dan adanya prasangkaprasangka yang muncul, hal-hal lain yang mempengaruhi kelompok Samin tidak begitu berbaur dengan masyarakat sekitar karena adanya norma yang mengikat warga terutama atu-ran yang mengikat kuat komunitas Samin sehingga membuat ruang gerak mereka lebih terbatas. Dengan adanya nor-ma/aturan yang mengikat komunitas Samin memberi pengaruh 
yang besar padafrekuensi interaksi yang dihasilkannya.Setiap orang mempunyai tingkat anxiety yang berbeda-beda. Jika anxiety sangat tinggi, seseorang dapat dipastikan akan kesulitan bahkan tidak mau berkomunikasi dengan orang asing. Seseorang hanya akan menggunakan stereotip dalam memprediksi perilaku orang asing. Sebaliknya, jika anxiety sangat rendah seseorang tidak akan merasakan adrenalin yang memotivasinya untuk berkomunikais dengan orang lain.

Menyangkut tingkatanxiety yang dialami oleh kelompok Samin, bisa dikatakan bahwa kelompok Samin mempunyai tingkat anxiety yang rendah karena antara kelompok Samin dan masyarakat masih mengalami interaksi walaupun interaksi yang terjadi sering mengalami kesalahan persepsi. Tingkat anxiety yang rendah itu ditandai dengan kelompok Samin masih terlibat dalam program-program yang ada di Desa. Interaksi yang terjalin antara komuni-tas Samin dengan masyarakat sekitar bersifat personal juga komunal. Dalam hal-hal tertentu mereka menjalin hubungan se-cara komunal seperti berinteraksi dengan pemerintah Desa. Maisalnya mengikuti program pemberantasan buta aksara, program KB, program penyedi-aan air minum dan sanitasi keluarga. Pertemuan antar warga misalnya pada acara halal bi halal dan penyuluhan program-program yang dilakukan oleh pemerintah. ${ }^{29}$

Pada uncertainty, Berger $\&$ Calabrese ${ }^{30}$ menyimpulkan bahwa ada dua jenis uncertainty yang muncul ketika berkomunikasi dengan orang asing. Pertama, uncertainty terhadap sikap, perasaan, kepercayaan, nilai dan perilaku. Ketika berkomunikasi dengan masyarakat sekitar, seseorang (kelompok Samin) perlu untuk memprediksi perilaku yang akan ditunjukan oleh orang asing yang dihadapi. Pada kelompok Samin mereka cenderung tidak bisa memprediksi perilaku yang akan ditunjukan oleh lawan bicaranya karena kelompok Samin cenderung tidak ingin tau, sehingga uncertainty yang dimunculkan semakin bertambah. Kedua, uncertainty terhadap makna dibalik perilaku yang ditunjukan oleh orang asing ketika berkomunikasi. Dalam hal ini, makna-makna yang dihasilkan kelompok Samin sulit untuk ditangkap oleh outgroupnya atau masyarakat sekitar sehingga masyarakat kebingungan saat memprediksi perilaku yang ditunjukan kelompok Samin.

\section{Pengelolaan Anxiety/Uncertainty kelompok Samin}

Gudykunst ${ }^{31}$ menyatakan bahwa ketika berkomunikasi dengan orang asing, kemampuan seseorang untuk berkomunikasi secara efektif didasarkan pada kemampuan untuk mengelola anxiety dan uncertainty. Ada berbagai macam faktor yang mempengaruhi anxiety dan uncertainty seseorang. Faktor-faktor tersebut berupa pengaruh sosiokultural, psikokultural dan lingkunga. Stephen \& Stephen ${ }^{32}$ menyimpulkan tiga kategori yang mempengaruhi anxiety seseorang. Ketiga kategori tersebut adalah hubungan antar 
kelompok yang telah lebih dulu terbangun, kesadaran dan pengetahuan antarkelompok serta faktor situasional.

Memang hubungan antara kelompok Samin dan masyarakat sekitar sudah lama terbangun, mengingat lingkungan trmpat tinggal mereka tidak begitu berjauhan, meskipun mereka tinggal berdampingan hubungan yang terjalin juga tidak begitu dekat karena terbentur dengan perbedaan norma serta budaya yang dimiliki kelompok Samin dan masyarakat sekitar. Akan tetapi perbedaan dan kesalahpahaman yang terjadi antara kelompok Smin dan masyarakat sekitar ini akan membuat anxiety dapat meningkat.

Faktor situasional yang mempengaruhi anxiety diantaranya adalah seberapa besar struktur mempengaruhi situasi dimana hubungan terjalin, bentuk ketergantungan antarkelompok, kelompok Samin juga melakukan kegiatan go-tong royong, gotong royong ini dilakukan oleh kelompok Samin apabila ada warga yang menyelenggarakan hajatan. Kegiatan tolong menolong bagi kelompok Samin merupakan berpedoman pada ajarannya.

Gudykunst ${ }^{33}$ menyimpulakn beberapa faktor yang mempegaruhi uncertainty. Faktor-faktor tersebut adalah: expectation (dugaan), social identity (identitas sosial), persepsi diantara kelompok sendiri dengan kelompok lain dan hal-hal interpersonal yang menonjol dalam komunikasi dengan orang lain.Well-defined expectations atau dugaan-dugaan yang datang dari luar tentang kelompok Samin adalah masyarakat sekitar menganggap jika berkomunikasi dengan kelompok Samin sering tidak nyambung, karena perbedaan penafsiran dari bahasa yang diucapkan keti-ka berkomunikasi. Tidak hanya perbedaan bahasa saja tetapi juga perbedaan budaya (ide, perilaku budaya, benda-benda hasil budaya). Meskipun demikian di antara ko-munitas Samin dan masyarakat sekitar tetap saling menghormati karena kelompok Samin berpedoman tentang kepercayaan ajarannya yaitu selalu menghormati orang lain.

Dalam teori anxiety/ uncertaintymanagement terdapat bagan skema representasi. Dalam skema tersebut memuat 21 aksioma yang dibagai dalam tujuh bagian berkaitan erat dengan anxiety dan uncertainty. Mindfulness merupakan bagian dari pengelolaan untuk mencapai komunikasi yang efektif, akan tetapi Langer ${ }^{35}$ menyatakan bahwa ketika seseorang menghadapi situasi komunikasi yang relatif baru, ia dengan sadar mencari isyarat-isyarat untuk menentukan berprilaku. Akan tetapi, apabila seseorang berulang kali menghadapi situasi komunikasi yang relatif sama, kesadarannya dalam berperilaku akan berkurang atau yang disebut dengan mindless.

Dalam hal ini, kelompok Samin bisa disebut kelompok yang mindless karena menghasilkan komunikasi yang membingungkan dengan masyarakat luar, karena seorang yang mindless dalam berkomunikasi tidak sepenuhnya memperhatikan apa yang ia katakan dan lakukan. Apabila masyarakat luar bertanya 
kepada kelompok Samin, jawabannya sering tidak rasional. Contohnya ketika seseorang bertanya kepada kelompok Samin "mau kemana?" maka jawaban yang didapat adalah "mau kedepan" dan jika bertanya “dari mana? ” maka jawaban yang didapat adalah "dari belakang". Ini merupakan salah satu contoh jawaban-jawaban yang tidak rasional dari kelompok Samin sehingga membuat orang bertanya menjadi bingung.

Kelompok Samin juga harus dapat mengakui bahwa ada beragam perspektif untuk menginterpretasikan pesan dalam situasi komunikasi. Ketika seseorang mindless, ia cenderung sulit untuk mengakui beragam perspektif. Seperti halnya kelompok Samin, perspektif yang mereka gunakan hanya kelompok mereka sendiri yang tau dan mereka tidak ingin melihat perspektif-perspektif yang ada pada outgroupnya. Jika kelompok Samin mengamalkan ketiga karakteristik ini, mungkin saja komunikasi yang terjalin dengan masyarakat diluar kelompok Samin lebih berjalan efektif.

\section{Penutup}

Sebab utama adanya anxiety dan uncertainty pada kelompok samin ialah kelompok samin tidak mengetahui orientasi budaya-budaya masyarakat luar (outgroup) sehingga membuat komunikasi yang terjalain antara kelompok Samin dan masyarakat tidak efektif. Dari segi bahasa, kelompok Samin mempunyai bahasa sendiri yaitu bahasa Jawa Ngoko, akibatnya sering terjadi ketidakpastian komunikasi antara keduanya.
Adanya dugaan-dugaan negatif dari outgroup-nya, membuat komunikasi yang terjadi penuh dengan dugaan-dugaan atau prasangka.

Faktor-faktor yang mempengaruhi anxietykelompok Samin dengan masyarakat sekitar sadar akan posisinya masing-masing. Kelompok Samin lebih menghormati masyarakat sekitar namun kelompok Samin bukanlah merupakan kelompok yang mayoritas dilingkungan sekitar sehingga mereka susah untuk mengurangi anxiety. Faktor-faktor yang mempengaruhi uncertainty adalah karena makna-makna yang dihasilkan kelompok Samin sulit untuk ditangkap oleh outgroupnya sehingga masyarakat kebingungan saat memprediksi perilaku yang ditunjukan kelompok Samin. Pengurangan uncertainty ditandai dengan kelompok Samin dan outgroup-nya tidak lantas membuat mereka saling bermusuhan, mereka masih saling berhubungan walaupun hubungan itu tidak terlalu mendalam.

Well-defined expectations yang datang dari luar tentang kelompok Samin bahwa outgroup menganggap jika berkomunikasi dengan kelompok Samin sering tidak nyambung, karena perbedaan penafsiran dari bahasa yang diucapkan keti-ka berkomunikasi. Tidak hanya perbedaan bahasa saja tetapi juga perbedaan budaya (ide, perilaku budaya, benda-benda hasil budaya). Kelompok Samin bisa disebut kelompok yang mindless dalam berkomunikasi karenakelompok Samin tidak sepenuhnya memperhatikan apa yang ia katakan dan lakukan dan tidak dapat mengkategorisasikan lawan bicaranya. 
Kelompok samin akan menjadi mindful ketika mereka bisa sedikit terbuka terhadap informasi-informasi yang datang dari luar kelompoknya dan mengakui bahwa ada beragam perspektif untuk menginterpretasikan pesan dalam situasi komunikasi antarbudaya sehingga komunikasi yang terjalin dengan outgroup lebih berjalan efektif.

\section{Endnote}

${ }^{1}$ Mumfangati, T. 2004. Kearifan Lokal di Lingkungan Masyarakat Samin kabupaten Blora Jawa Tengah. Yogyakarta: Jarahnita.

${ }^{2}$ Liliweri, Alo. 2004. Dasar-Dasar Komunikasi Antarbudaya. Yogyakarta: Pustaka Pelajar

${ }^{3}$ Samovar, Larry A. et al. 2010. Komunikasi Lintas Budaya (Indri Margaretha Sidabolak. Terjemahan). Jakarta: Salemba Humanika

${ }^{4}$ ibid

${ }^{5}$ Griffin, Em. 2006. A First Look at Communication Theory Sixth Edition. New York: McGraw-Hill, Hal. 427

${ }^{6}$ ibid

${ }^{7}$ Ibid. Hal 431.

${ }^{9}$ Nancy Lee Peluso, Rich Forest Poor People: Resource Control and Resistance in Java. Dalam Acmad Uzair Fauzan, Politik Representasi dan Wacana Multikulturalisme dalam Praktek Program Komunitas Adat Terpencil (KAT) Kasus Komunias Sedulur Sikep Bombong-Bacem. Dalam Mokh. Sobirin, Op.Cit, hal 3.

${ }^{10} \mathrm{Ibid}$, Hal 6-7.

${ }^{11}$ Titi Mumfangati, dkk. 2004.Kearifan Lokal di Lingkungan Masyarakat Samin Kabupaten Blora Jawa Tengah. Yogyakarta: Jarahnitra

\section{${ }^{12}$ ibid}

${ }^{13}$ Film Dokumenter "Kula Ndiko Sami", Jakarta: In-Docs dan Paguyuban Kadhang Sikep, 2005.
${ }^{14}$ Mumfangati, T. 2004. Kearifan Lokal di Lingkungan Masyarakat Samin kabupaten Blora Jawa Tengah. Yogyakarta: Jarahnita.

${ }^{15}$ Ibid

${ }^{16}$ Griffin, Em. 2006. A First Look at Communication Theory Sixth Edition. New York: McGraw-Hill, Hal. 429

${ }^{17}$ Gudykunst, William B. \& Young Yun Kim. 2003. Communication with Strangers an Approach to Intercultural Communication 4th Edition. New York: McGraw-Hill, hal. 229

${ }^{18}$ Griffin, Em. 2006. A First Look at Communication Theory Sixth Edition. New York: McGraw-Hill, Hal. 429

${ }^{19}$ Dalam Gudykunst, William B. \& Young Yun Kim. 2003. Communication with Strangers an Approach to Intercultural Communication 4th Edition. New York: McGraw-Hill, hal. 232

${ }^{20}$ Ibid,. Hal. 235

${ }^{21}$ Dalam Gudykunst, William B. \& Young Yun Kim. 2003. Communication with Strangers an Approach to Intercultural Communication 4th Edition. New York: McGraw-Hill, hal. 239

${ }^{22}$ Ibid, hal. 234-235

${ }^{23}$ Ibid. Hal. 240

${ }^{24}$ Ibid. Hal. 251

${ }^{25}$ Ibid

${ }^{26}$ Ibid

${ }^{27}$ Dalam Rahardjo, Turnomo. et al.2013. LiterasiMedia dan Kearifan Lokal. Mata Padi Pressindo

${ }^{28}$ Dalam Griffin, Em. 2006. A First Look at Communication Theory Sixth Edition. New York: McGraw-Hill Hal. 429

${ }^{29}$ Dalam Rahardjo, Turnomo. et al.2013. LiterasiMedia dan Kearifan Lokal. Mata Padi Pressindo

${ }^{30}$ Dalam Gudykunst, William B. \& Young Yun Kim. 2003. Communication with Strangers an Approach to Intercultural Communication 4th Edition. New York: McGraw-Hill.

${ }^{31} \mathrm{Ibid}$
${ }^{32} \mathrm{Ibid}$
${ }^{33} \mathrm{Ibid}$
${ }^{34} \mathrm{Ibid}$
${ }^{35} \mathrm{Ibid}$
${ }^{36} \mathrm{Ibid}$ 